typhoid. Early in the war, the bad news came of many cases of tetanus; the heavily manured soil of France was full of tetanus; the very earth that our men were helping to defend was their enemy. It is a great blessing that a wounded man may indeed be safeguarded, with a dose of anti-tetanic serum, against this disease; and a great blessing that our men now are on soil which is fairly free from it.

But typhoid, after all, is the supreme test of the efficiency of an army medical service. We have learned of late years that the infection may be conveyed by flies, and by clouds of dust; we have learned also the danger of infection from mild, unsuspected cases, and from typhoidcarriers; we have left off thinking that typhoid cannot be spread without the help of a "polluted water supply." The present control of typhoid for our Army in France has been won by the bacteriologists; all honour to them :-

Mobile bacteriological laboratories have been installed expressly for this purpose (the early detection of cases). Each laboratory consists of a motor-lorry fitted with a complete bacteriological equipment, and is in charge of a specially-trained officer, and an attendant of the Royal Army Medical Corps.

Moreover, it is the bacteriologists who discovered the protective treatment against the disease. On March 5 we learned what our Army owes to that treatment. Of fifty deaths from typhoid fever among our men on active service, forty-eight had occurred among the non-protected, one in a man protected, and one in a man partly protected. Nobody in his proper senses can doubt that Nature finds it easier to kill the nonprotected than to kill the protected.

It must not be forgotten that by far the most potent weapon in our armoury against typhoid fever has been forged by pathologists, before the war. Inoculation is the surest defence : and to its extensive use must chiefly be attributed the low incidence of this terrible disease in the British Army.

But the whole article ought to be read carefully, not in fragments.

Doubtless, when the hot weather comes, the work of safeguarding the Army's health will be no less arduous than it is now. For the present, let us be thankful for the splendid services rendered by men of science to our defenders, through all the bitter hardship and perils of the past nine months.

Stephen Paget.

\section{THE USE OF ASPHYXIANTS IN} WARFARE.

THE use of asphyxiating gases by the Germans 1 in forcing back the French lines to the north of Ypres has given rise to much conjecture as to the nature of the gases employed, and in a long article in a Sunday paper it is surmised that the gas used was carbon monoxide. The only foundation that can exist for such an opinion is that carbon monoxide is one of the most virulent gaseous poisons known: and that less than I per cent. in air rapidly proves fatal, but inasmuch as all the explosives in general use produce it in large quantities, the smokeless powders in use by
England, France, and Germany, giving approximately $5^{\circ}$ per cent. of the permanent gases formed as carbon monoxide, it is hard to believe that the enormous volume produced by firing the charge in the gun should have no deleterious effect on those using it, whilst the much smaller quantity given on the bursting of the shell should asphyxiate the enemy. The fact is, that carbon monoxide is slightly lighter than air, and when driven out by the explosion in a heated condition diffuses upwards so rapidly that scarcely a trace can be found at the breathing level, but when evolved underground in a confined space many accidents have been caused by its poisonous properties.

Moreover, carbon monoxide is in no sense of the word an asphyxiant, 'frid one of its greatest dangers lies in the fact that air containing a poisonous amount can be readily breathed.

Later reports received on Monday and Tuesday make it evident that it was a true asphyxiant, such as sulphur dioxide, chlorine, or a mixture of the two that was employed, and that the fumes generated in front of the German trenches were borne down by a northerly wind upon the Allies. Some descriptions speak of the burning of some substance which gave a yellowish smoke and gases; others that the gases were contained in steel cylinders, the gases being conducted by hosepipes some little distance in front of the trenches, whilst the men manipulating the cylinders wore divers' helmets, and the first German troops to charge over the gassed area wore smoke helmets or respirators. It is further probable that some shells containing a liquid giving gases of an asphyxiating character were also employed.

It seems to be clear from various descriptions that the gases floated close to the ground for a considerable distance, producing an effect of asphyxiation, which was felt as far as the Allies' second lines.

Both sulphur dioxide and chlorine would have produced the effects described, and the cylinders spoken of might have contained these gases in a iiquefied form, whilst it is probable that shells used for asphyxiating purposes would be charged with chloride of sulphur which would itself decompose in moist air or in contact with water into sulphur dioxide, hydrochloric acid, and sulphur, or, if fired by the bursting of the shell, would give sulphur dioxide and chlorine.

Both sulphur dioxide and chlorine satisfy the requirements of being more than double the weight of air, and so might remain near the ground, diffusion being only slow, but it is difficult to understand how sufficient quantities of either gas were produced to render the air irrespirable at the distance of the Allies' lines from the German trenches.

\section{RICHARD LYDEKKER, F.R.S.}

ROTH zoologists and geologists lament the $B$ death on April 16 of Mr. Richard Lydekker, who had been for more than thirty years one of the most active workers in the natural history sciences. Born in 1849 , of Dutch descent, he was educated at Cambridge, where he graduated

No. 2374, VOL. 95] 